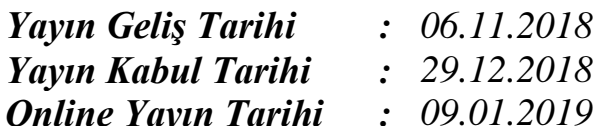

Online Yayın Tarihi : 09.01 .201
Doi: $10.24988 /$ deuiibf.2018332808
Dokuz Eylül Üniversitesi

İktisadi ve İdari Bilimler Fakültesi Dergisi

Cilt:33, Sayl:2, Yll:2018, ss.657-678

\title{
Belediye Çalışanlarının Mutlulukları: Manisa Büyükşehir Belediyesi Örneği ${ }^{1}$
}

\author{
Hüriyet BÍLGE ${ }^{2}$
}

\begin{abstract}
$\ddot{\mathbf{O} z}$
Büyükşehir belediyelerin sayısal bazda artmalarl ve 2014'ten sonra sorumluluk alanlart il sınırlarına çekilmesiyle birlikte hizmet sunumlarında büyük bir artış görülmüştür. Hizmet sunumlarındaki olağanüstü artışı belediye çalışanlarına daha fazla yük ve sorumluluk getirmiştir. Bu bağlamda belediye çalışanlarının kişisel mutluluklarının cinsiyet, yaş, medeni durum, eğitim, unvan, sosyal yaşama katılma ve meslekteki toplam çalışma süresi gibi farkl demografik değişkenler açısından incelenmiştir. 203 Manisa Büyükşehir merkez belediye çalışandan Oxford Mutluluk Ölçeği kullanılarak elde edilen veriler aracılı̆̆ılyla öncelikle Açılkayıcı Faktör Analizi (AFA) uygulanmış ve beş alt boyut elde edilmiştir. Verilerin analizi için "t testi" ve "Tek yönlü varyans analizi" uygulanmıştır. Yapılan analizler sonucunda, araştırmaya katılan belediye çalışanlarının mutluluklarl "cinsiyet, medeni durum, eğitim, unvan, ve sosyal yaşama katılma" değişkenlerine göre anlamll farklllıklar ortaya koyduğu; "yaş ve meslekte çalışma süresi" gibi değişkenlere göre ise anlaml farklılıklar ortaya çıkmadı̆̆ belirlenmiştir.
\end{abstract}

Anahtar Kelimeler: Mutluluk, Oxford Mutluluk Ölçeği ve Faktör analizi

Jel Kodları: D23, M19

\section{Happiness of Municipal Employees: The Case of Manisa Metropolitan Municipality}

\begin{abstract}
The increase in the number of metropolitan municipalities and the extension of their responsibility areas to the provincial borders after 2014, there has been a large increase in their service offerings. This extraordinary increase in service offerings has brought more workload and responsibility to municipal employees. In this context, the personal happiness levels of the municipality employees was examined in terms of different demographic

\footnotetext{
1 Bu Makale, 7-11 Kasım 2018 Kemer-Antalya'da düzenlenen IV. Uluslararası Stratejik Araştırmalar Kongresi (ISRC)'nde sunulmuş çalışmanın düzenlenmiş ve genişletilmiş halidir.

${ }^{2}$ Dr. Öğr. Üyesi, Manisa Celal Bayar Üniversitesi, Uygulamalı Bilimler Yüksekokulu, Bankacılık Finans Bölümü, hurriyet.bilge@gmail.com
} 


\section{H. BİLGE}

variables such as gender, age, marital status, education, title, participation in social life, total working time in the profession and unionization. Explanatory Factor Analysis (EFA) was applied to the data of 203 personnel of Manisa Metropolitan Municipality by using Oxford Happiness Scale; and five sub-dimensions were obtained. For the analysis, "t test" and "one-way analysis of variance (ANOVA) was preferred. According to the analyzes, it was found that the happiness levels of municipal employees showed significant differences in terms of happiness, gender, marital status, education, title, and participation in social life. ON the contrary, the happiness levels didn't significantly differ in regard to age, total working time in the profession and unionization.

Keywords: Happiness, Oxford Happiness Scale, Factor Analysis

\section{GİRİş}

"1982 Anayasası'nın 127’nci maddesine göre mahalli idareler il, belediye veya köy halkının mahalli müşterek ihtiyaçlarını karşılamak üzere kuruluş esasları kanunla belirtilen ve karar organları gene kanunda gösterilen, seçmenler tarafindan seçilerek oluşturulmuş kamu tüzel kişileridir" (Sevgili Gençay, 2018: 154). Tanımda da belirtildiği üzere belediyeler, belediye sınırları içerisinde yaşayan halka hizmet üretmek ve sunmakla yetkilendirilmiş kamu tüzel kişiliğe sahip kurumlardır. Belediye çalışanlarının, hizmet sunumu tamamen belediye sınırları içerisindeki yaşayan halk olduğu için, hizmetin üretimi ve sunumu sırasında hizmeti alan vatandaşa karşı daha duyarlı, nazik ve etkin olabilmesi hem kişisel hem kurumsal olarak önemlidir. Belediyelerden hizmet alan halka karşı daha etkin hizmet üretebilmek ve sunabilmek için belediye çalışanlarının da rahat, huzurlu ve mutlu olması gerekir. Kamthan vd. (2018) mutlu bir insan, kendisi ve başkaları hakkında her zaman iyi ve güzel hisler taşır. Böyle içsel bir mutluluğa sahip kişi yalnızlıktan vazgeçer, kişisel kusurlarını kabul eder, öğrendiklerini asla unutmaz, daima kendine ve başkalarına karşı dürüsttür, yaşadığı ana odaklanır, bir anlamda farkındalığa sahiptir ve karşılaştığı sıkıntılara karşı daha dayanıklıdır.

Kurumlarda, mutlu çalışanların varlı̆̆ kurumun amaçlarını gerçekleştirmesi bakımından önemlidir. Çalışanlarda yaşam doyumu ya da kişisel mutluluklarını arttıracak ve aynı zamanda işyerlerinde de mutlu olmalarını sağlayacak etkenler; huzur sağlayıcı kurum kültürü, değer verilme, yetkilendirme, kariyer ve performansa önem verilmesi, adil ve şeffaf bir yönetim ve fikirlerinin dikkate alındığı bir iletişim ortamı gibi birçok faktör sıralamak mümkündür. Belediyeler, yerel halkın oy 
çokluğu ile seçildikleri ve iş başına geldikleri için kendi vatandaşlarına karşı daha demokratik, daha şeffaf olmaları ve onlara hesap verebilmeleri için tüm organizasyon olarak birlikte ve bir bütün halinde davranış sergileyebilmeleri her iki taraf için önemlidir.

Günümüzde, kurumların belirledikleri hedeflere ulaşabilmeleri için doğru bir yönetim biçimi belirlemelerine ve uygulamaya koyabilmelerine bağlıdır. Bunun için, öncelikle iyi ve esnek ekiplerin oluşturulması ve ekip üyelerin tatmini ve mutluluğu onların öğrenme motivelerini sağlama yolunda tetikleyici ve belirleyici unsurlar olacaktır. Kurumlarda, çalışanların mutlulukları niçin önemlidir sorusuna cevaplar siralamak mümkündür:

- Çalışanların içsel motivasyonlarını sağlama ve farkındalıklarını arttırabilme,

- İyi bir ekip oluşturabilme ve oluşturulan ekibin uyumunun sürekliliğini sağlama,

- Öğrenme sürecini kurumda, kültür haline getirebilme,

- Kurumlarda insan kaynakları odaklı maliyetlerde azaltım sağlama,

- Kurum içerisinde ani ortaya çıkan sorunların çözümünde,

- Hedeflere ulaşabilme yolunda iç girişimcilik davranımlarının ortaya konmasinda $\mathrm{vb}$.

Literatürde, Büyükşehir Belediyelerinde çalışanların demografik değişkenler bağlamında salt mutluluğunu araştıran çalışmalar yerine daha çok iş tatmini ve iş doyumu üzerine belirli az oranda çalışmalar mevcuttur. Mutluluk üzerine çalışmaların olmaması, mutluluğun daha çok 1980'lerden sonra pozitif psikolojinin ele aldığı konular arasında yer almasındandır. Günümüzde bilimsel alanlar arasında sürekli geçişlerin yapıldığ 1 görülmekte ve organizasyonlar la ilgili çalışmalarda tükenmişlik, girişimcilik, kültür, sinizm vb. konuların yanı sıra mutluluk ta araştırılan konular arasına girmiştir. $\mathrm{Bu}$ bağlamda, çalışmanın temel amacı demografik değişkenlerin çalışanların mutluluğunda fark oluşturup oluşturmadığ 1 önsavını doğrulamaya çalışmaktır. Çalışmada istatistiki birimi 2018 Ağustos-Eylül ayları içinde Manisa Büyükşehir Belediyesi il merkezi tüm çalışanlar olarak tanımlanmıştır. Anket iki ay süresince tüm çalışanlar içinden ulaşılabilen 203 


\section{H. BİLGE}

çalışanla yüz yüze yapılmış ve çalışma örneklemimizi oluşturmuştur. Çalışmanın ilk aşamasında Oxford Mutluluk Ölçeği (OMÖ) uzun formunun boyutlarının belirlenmesi için Açıklayıcı Faktör Analizi (AFA) yapılmış ve daha sonra Lisrel 8.8 ile belirlenen boyutların güvenirliği sağlayıp sağlamadığını ortaya koymak için Doğrulayıcı Faktör Analizi (DFA) yapılmıştır.

\section{LITERATÜR TARAMASI}

Mutluluk, genellikle iyi olmayı ve iyi yaşamı tarif etmek için kullanılan orijinal Yunanca (eudaimonia)'dan tercüme edilen modern bir kelimedir. Mutluluk, zaman içinde iyi yapmak ve iyi yaşamakla başarılması mümkündür (Gavin ve Mason, 2004: 379). Mutluluk, bireyin kendi hayatının genel kalitesini olumlu bir şekilde değerlendirdiği derece olarak düşünülür. Başka bir deyişle, amaçları doğrultusunda belirlemiş olduğu hayatı ne kadar çok seviyor olmasıyla doğru orantılı olan (Veenhoven, 1990: 2), insan yaşamında çok önemli bir faktördür. Mutlu bir insanın, iç mutluluğa sahip olması için sağlıklı olması, profesyonel yaşamını sürekli geliştirmesi ve diğer insanlara yardım edebilmesi için gereklidir (Kamthan vd. 2018). Aristoteles, genellikle "mutluluk" olarak tercüme edilen eudaemonia, insanların nihai hedefi olarak ve diğer ulaşılması istenen tüm hedeflerden üstün kılmıştır (Diener vd. 1998: 34). Bu nedenle, mutluluk insanlar arasında en çok istenen durum olarak düşünülebilir ve diğer hedefler sadece mutluluğun potansiyel belirleyicileri olarak değerlendirilebilir (Medvedev vd., 2017: 1426'den akt., Csikszentmihalyi, 1992). Bugün, Aristoteles'in tasarladığı gibi mutluluğun birçok insanın hayatında eksik olan bir şey olması daha çok modern işyeri yönetim biçimlerinden kaynaklanmaktadır (Gavin ve Mason, 2004: 379). Bu bağlamda, mutluluğun zaman içinde göreceli olarak kararlı ve olaylar (durumlar) arasında tutarlı görünmektedir. Psikolojide, mutluluk "duygu” olarak tanımlanır. Duygu "negatif duygu" ve "olumlu duygu" olarak ikiye bölünür ve insanların kişisel ve iş başarısı üzerinde önemli etkiye sahiptir. Mutlu insanlar olaylara iyimser yaklaşır ve iyimser davranırlar. Psikologlar, mutluluğun olumlu duyguların göreceli olarak var oluşu, olumsuz duygular ve yaşam doyumu olmak üzere üç ana unsura sahip olduğuna inanmaktadır (Kamthan vd. 2018). 47 ülkede yürütülen kültürler arası 
araştırmalar, mutluluğun sağlik, sevgi ya da zenginlik gibi diğer kişisel değerlerden daha yüksek olduğunu göstermiştir (Kim-Prieto vd. 2005: 262). Benzer olarak, Skevington vd. (1997) İngiltere'deki bir dizi odak grubu ile mutluluğun, örneğin "yaşam kalitesinin" en önemli bileşeni olarak para, sağlık veya cinsellikten daha yüksek olduğu şeklinde elde etmişlerdir (Argly, 2013: 1).

Oxford Mutluluk Envanteri (OHI), (Argyle, Martin ve Crossland, 1989) 1980'lerin sonunda Oxford Üniversitesi Deneysel Psikolojisi Bölümde çoğunlukla kurum içi kullanım için kişisel mutluluğun geniş bir ölçüsü olarak tasarlanmıştır (Hills ve Argly, 2002: 1073-1074). Bu yönde, Hills ve Argyle (1998) yaşları 18-82 arasında 275 katılımcıya uyguladıkları Oxford Mutluluk Envanteri (OHI) ile onların ortak dört boş zaman aktivitelerinin (spor/konuşma, müzik, kilise ve tv dizileri) oluşturduğu olumlu ruh halleri üzerine yaptıkları çalışmada, her aktivitenin olumlu ruh halleri açısından anlamlı olduğunu bulmuşlardır. Oxford Mutluluk Ölçeği (OMÖ)'ni Türkçe'ye uyarlamak ve psikometrik özelliklerini incelemek amaciyla Doğan ve Çötok (2011) tarafindan OMÖ orijinal formundan Türkçe’ye çevirisi yapılmış ve dilsel anlamda gerekli kontroller yapılmıştır. OMÖ'nin ölçeğin Türk katılımcıların kişisel mutluluğunu ölçmede kullanılabilecek geçerli bir ölçek olduğu sunulmuştur.

Yüksekbilgili ve Akduman, (2015) İstanbul Aile Hekimleri arasında yaptıkları çalışmada, cinsiyet, eğitim ve işyerindeki pozisyon demografik değişkenlerinin kişisel ve işyeri mutluluk sağlamada fark oluşturmadığı ve sadece eğitim ile fark oluşturduğu sonucunu elde etmişlerdir. Demografik değişkenlerin mutluluğu etkileme konusunda Kamthan vd. (2018) üniversite öğrencilerinin demografik değişkenlerinden cinsiyete göre mutluluk dağılımında, seçilen tıp öğrencilerinin\% 60.8'inin mutlu grupta olduğunu elde etmişlerdir. Erkek öğrencilerin (\% 51.4) kadınlardan (\% 48,6) daha mutlu oldukları bulunmuştur. Ayrıca, nispeten genç kardeşlerin daha mutlu olduğu gözlenmiştir. Öğrencilerin daha yüksek güce veya evrensel bilince inananlar daha hoşnut ve daha mutlu oldukları bulunmuştur. Demografik değişkenler konusunda Ege (2018) İzmir Gediz Dağıtım A.Ş. de yaptığı 


\section{H. BİLGE}

çalışmada, çalışanların demografik değişkenlerden sadece medeni durumun mutluluk üzerinde anlamlı bir etkiye sahip olduğunu belirlemiştir.

\section{ARASTIRMANIN YÖNTEMI}

\subsection{Yöntem}

Manisa Büyükşehir Belediyesi il merkezinde tüm birimlerde çalışanların cinsiyet, yaş, medeni durum, eğitim, unvan, sosyal yaşama katılma ve meslekteki toplam çalışma süreleri gibi değişkenlerin mutluluk alt boyutlarına göre farklılık gösterip göstermediğini belirlemek amacıyla yapılan bir saha çalışmadır.

Araştırmanın bağımlı değişkenleri belediye çalışanlarının kişisel mutluluk düzeyleridir. Araştırmanın bă̆ımsız değişkenleri; cinsiyet, yaş, medeni durum, eğitim, unvan, sosyal yaşama katılma ve meslekteki toplam çalışma süresi vb. demografik değişkenlerdir.

\subsection{LİSREL ile Yapısal Eşitlik Modellemesi (YEM)}

YEM çalışmalarının başlıca temel özelliği tamamen bir teoriye dayandırılmasıdır (Şimşek, 2007: 1). Yapısal eşitlik modellemesi (YEM), gözlenen ve gözlenemeyen (gizil) değişkenler arasındaki nedensel ilişkilerin sınanmasında ve karşılıklı ilişkilerin bir arada bulunduğu modellerin testi için kullanılan kapsamlı istatistiksel bir tekniktir. YEM, belirli bir çalışma ile ilgili yapısal kuramın çok değişkenli analizine hipotez testi yaklaşımı getiren önemli istatistiksel yöntemler dizisi olarak kabul edilir. Bu yapısal kuram, birçok değişken üzerinde gözlemlenen nedensellik süreçlerini göstermektedir (Şimşek, 2007: 7-10; Byrne, 1998: 3; Yılmaz vd., 2009:118; Kline, 2011:5). Aynı zamanda, kuramsal yapıların formüle edilmesiyle karşılaşılan problemlerin çözümünde faydalı olabilmektedir. Özellikle de, değişkenler arasındaki ilişkilerin değerlendirilmesinde, belirlenen kuramsal modellerin geliştirilmesi ve test edilmesinde genellikle kullanılmakta ve YEM'in uygulama aşamaları şöyledir (Çelik ve Yılmaz, 2013: 5):

- Kuramsal bir modelin geliştirilmesi, 
- Çalışmada geliş̧irilen kuramsal model için nedensel ilişkilerin gösterildiği path diyagramının çizilmesi,

- Önerilen modele ilişkin tahminlerin elde edilmesi

- Çalışmada elde edilen yapısal modelin genel olarak değerlendirilmesi, model uygunluğunun değerlendirilmesi ve elde edilen sonuçların yorumlanmasidir.

Yapısal Eşitlik Modelinde (YEM) kullanılan birden fazla model uyum iyiliği test istatistikleri vardır. Literatür incelendiğinde YEM' de en çok kullanılan test istatistikleri; benzerlik oranı Ki-Kare istatistiği $\chi^{2},\left(\chi^{2} /\right.$ s.d.)'dir. Bir test istatistiği olarak Ki-Kare $\left(\chi^{2}\right)$ benzerlik oranı yerine, $\operatorname{Ki-Kare~}\left(\chi^{2}\right)$ nin üçten daha büyük değerler için kötü bir uyum bunan karşılık küçük Ki-Kare $\chi^{2}\left(\chi^{2} /\right.$ s.d $<3$ ise) değerlerinde iyi bir uyumdur; GFI (Uyum iyiliği indeksi-Goodness-of-fit indeks); AGFI (Uyarlanmış uyum iyiliği indeksi- Adjusted goodness-of-fit index); RMSEA (Ortalama hata karekök yaklaşımı- Root-mean-square error approximation) olarak yer alır RMSEA $\leq$ 0,05 olması mükemmel bir uyuma, 0,08-0.10 arasındaki değerleri kabul edilebilir bir uyumdur. Göreli varyans ve kovaryans miktarının bir göstergesi olan GFI ve CFI(Karşılaştırmalı uyum indeksi- Comparative Fit İndex) ve NFI(Normlandırılmış uyum indeksi-The Normed Fit İndex), 0-1 arasında değer alır ve bu değerin 1'e yakınlığı modelin uygunluğunun daha iyi olduğunu gösterir. Diğer uygunluk ölçütleri, CFI (Karşılaştırmalı uyum indeksi- Comparative fit index), NFI (Normlandırılmış uyum indeksi-The Normed fit index) dir. Yukarıdaki ölçütler de 0-1 aralığında değişen değerler alır ve 1'e yakınlığı modelin uygunluğunu gösterir. Ayrıca yüklerin her biri ile ilişkili olan t değerleri 2'den daha büyük ise bulunan yük değerlerinin istatistiksel olarak anlamlı olduğu kabul edilir (Y1lmaz vd., 2010:329; Hox ve Bechger, 2011: 364; Jöreskog ve Sörbom, 1996-2001:28-30; Schermelleh-Engel, 2003:31-32). 


\section{H. BİLGE}

\subsection{Evren ve Örneklem}

Araştırmanın evreni, Manisa Büyükşehir Belediyesi il merkezinde 2018 AğustosEylül dönemlerinde tüm birimlerde çalışanlardan oluşmaktadır. Araştırmanın örneklemini kolayda örnekleme metoduyla yüz yüze belirlenmiş olan 203 belediye çalışanlarından oluşmaktadır.

\subsection{Veri Toplama Araçları}

Çalışmada veri toplama aracı olarak Kişisel Bilgi Formu ile Oxford Mutluluk Ölçeği kullanılmıştır. Kişisel Bilgi formu bağımsız değişkenlere ait bilgileri toplamak için araştırmayı yapan tarafından geliştirilen veri toplama aracıdır. $\mathrm{Bu}$ formda araştırma grubuna yönelik cinsiyet, yaş, medeni durum, eğitim, unvan, sosyal yaşama katılma ve meslekteki toplam çalışma süresi vb. demografik değişkenler ile ilgili sorular yer almıştır.

Araştırmada kullanılan Oxford Mutluluk Ölçeği (OMÖ), belediye çalışanlarının demografik değişkenlerinin mutluluk alt faktörleri üzerindeki etkiyi belirlemek için, Hills ve Argyle tarafindan (2002) geliştirilmiş 29 maddelik ve 6'lı Likert olarak tasarlanmış fakat bu çalışmada 6'lı yerine 5'li likert tipi (Kesinlikle Katılmıorum(1), Katılmıyorum(2), Kararsızım(3), Kat1liyorum(4), Kesinlikle Katılıyorum(5), cevap seçeneği kullanılmıştır. Ölçekteki 6. 10. 13. 14. 19. 23.24. 27. 28. 29. no'lu sorular tersten kodlanmıştır. Ölçeğin Türkçe uyarlaması Doğan ve Çötok (2011) tarafından yapılmıştır. Hills ve Argyle (2002), ölçeğin iç tutarlılık katsayısını (168) (Cronbach alfa) 0.91 olarak rapor etmişlerdir. Ölçeğin yapı geçerliliğini belirlemek üzere yapılan faktör analizi sonucu, özdeğer kriteri 1'in üzerinde olan çok sayıda faktör elde edilmiştir. Fakat elde edilen faktör sayısı ardışık olarak yediden üçe düşürülerek alternatif faktörleme yapılmış fakat elde edilen faktörler için yorumlana bilirlik sağlanamamış ve aynı zamanda toplam varyans değeri kabul edilemez bir dereceye düşmüştür. Söz konusu faktörlerin yorumlanması ve adlandırılmasındaki problemler nedeniyle, OMÖ’nün tek faktörlü olarak kullanılmasının uygun olacağı sonucuna varmışlardır. Bu çalışmada, OMÖ'nün uzun formu faktör analizi sonucunda altı faktör elde edilmiş, 6. faktör iki soru içerdiği için analize dahil edilmemiş ve diğer beş faktörün özdeğerleri uygun çıktığı için isimlendirmeleri de yapılmış ve analize dahil edilmişlerdir. Toplam 29 sorudan 
oluşan Oxford Mutluluk Ölçeği (OMÖ) "yaşam memnuniyeti”, "Hoşnutsuzluk", "etkililik", "neşeli olma” ve "güvensizlik" olmak üzere beş alt boyutta değerlendirilmektedir.

\section{BULGULAR}

Yılmaz ve Şen (2013)'e göre faktör analizi, gözlenen ve gözlenemeyen (gizillatent) değişkenler arasındaki ilişkileri araştırmak için en iyi bilinen ve uygulanan bir istatistiksel tekniktir. Faktör analizinin Açıklayıcı Faktör Analizi (AFA) ve Doğrulayıc1 Faktör Analizi (DFA) gibi iki türü bulunmaktadır. AFA, gözlenen ve gizil değişkenler arasındaki bağlantıların kesin olmadığında kullanılır. Buna karşılık DFA ise sadece yem modelinde yer alan gözlenen ve gizil değişkenler arasındaki bağlantıların dikkate alındığı modeldir ve aynı zamanda ölçüm modeli olarak da adlandırılır. Araştırmacı, temeli oluşturan gizil değişken yapısı hakkında bilgiye sahip olduğunda AFA yerine DFA'yı kullanabilir.

\subsection{Araştırmanın Demografik Yapısı}

Araştırmaya katılanların \%40,9'u kadın, \%59,1'i erkek; \%29,1'nin yaşı 18-29 arasında, \%35,5'nin yaşı 30-35 arasında, \%23,2'nin yaşı 36-41 arasında ve $\% 12,3$ 'nün ise 42 ve yukarı yaşlardadırlar. Evli belediye çalışanların oranı $\% 72,4$ ve bekarların \%20,2 ve dul-boşanmış ise \%15 tir. İlk-orta öğretim mezunu belediye çalışanların oranı \% 45,3, ön lisans \% 21,2, lisans \% 32 ve yüksek lisans ise \% 1,5 tur. Araştırmaya katılan müdür/m.yrd.'larının oranı \% 1, amir/komiser/şeflerin oranı \% 3,9 ve memur/işçilerin oranı ise 95,1; meslekte çalışma süresi olarak \%45,3'ü 15 y1l, \% 43,3'ü 6-15 ve \%11,3’ü ise 11 ve daha fazla süredir çalışmaktalar. Belediye çalışanlarının sosyal yaşama katılımlarında "çok" olanların oranı $\% 10,3$, orta $\% 60,1$ ve sosyal yaşama fazla katılıyorum diyenlerin oranı ise \%29,6 dır. Bir hastalığa sahip olma 'da yok diyenlerin oran $\% 87,2$, bedensel $\% 7,9$, ruhsal $\% 2,5$ ve bedenselruhsal diyenlerin oran 1 ise $\% 2,5$ dolayındadır.

\subsection{Açıklayıcı Faktör Analizi (AFA) ve Doğrulayıcı Faktör Analizi (DFA)} Açıklayıcı Faktör Analizi Sonuçları: 


\section{H. BİLGE}

Tablo 1: Açıklayıcı Faktör Analizi Sonuçları

\begin{tabular}{|c|c|c|c|c|c|c|c|c|}
\hline \multirow[t]{2}{*}{ Faktörler } & $\begin{array}{l}\text { Faktör } 1 \\
\text { Yaşam } \\
\text { Memnun. }\end{array}$ & \multicolumn{2}{|c|}{$\begin{array}{l}\text { Faktör } 2 \\
\text { Hoşnutsuzluk }\end{array}$} & \multicolumn{2}{|c|}{$\begin{array}{l}\text { Faktör } 3 \\
\text { Etkililik }\end{array}$} & \multirow[t]{2}{*}{$\begin{array}{l}\text { Faktör } 4 \\
\text { Neşeli Olma }\end{array}$} & \multicolumn{2}{|c|}{$\begin{array}{l}\text { Faktör } 5 \\
\text { Güvensizlik }\end{array}$} \\
\hline &, 753 & Soru 28 & .630 & Soru26 & 688 & & Soru23 & ,768 \\
\hline &, 724 & Soru1 & ,576 & Soru17 & 620 & Soru18 ,596 & Soru10 &, 540 \\
\hline &, 568 & Soru19 & ,494 & Soru2 & 609 & Soru12,594 & Soru27 & ,405 \\
\hline &, 508 & & & Soru16 &, 554 & & & \\
\hline &, 491 & & & Soru 22 & .542 & & & \\
\hline &, 473 & & & Soru 20 & ,488 & & & \\
\hline &, 457 & & & Soru8, & ,486 & & & \\
\hline \multicolumn{9}{|c|}{ Soru 15,424} \\
\hline Varyans & 29,16 & & 6,805 & & 6,077 & 4,983 & & 4,595 \\
\hline Özdeğer & 7,254 & & 1,701 & & 1,519 & 1,246 & & 1,149 \\
\hline
\end{tabular}

KMO $=0.861 ; \quad$ Açıkla. Top. Vary.: 55,69

Bartlett Sınaması Değeri = 1685,33; $\quad p=0,000$

Anket yardımıyla elde edilen verilere faktör analizinden önce güvenirlik testi yapılmıştır. İlk olarak 29 ifadeye ilişkin güvenirlik testi uygulanmış ve Cronbach’s Alfa değeri 0,583 değeri, ikinci aşamada en yüksek değere sahip olan L14 sorusu analizden çıkartıldığında Cronbach's Alfa değeri 0,612'ye ve daha sonra en yüksek değere sahip olan L6, L24 ve L29 soruları analizden çıkartıldığında Cronbach’s Alfa değeri 0,700’e ulaşmıştır. Geriye kalan 25 ifadenin analiz sonucunun yeterli güvenirliğe sahip olduğu belirlenmiştir.

Yapılan çalışmada, ölçme sonucu elde edilen farklı ölçümler sonucunda sonuçların aynı ya da çok yakın değerler olması araştırma sonuçlarının güvenirliğini ve tesadüfi olmadığını bize anlatır. Bu bağlamda güvenirlik, bilimsel araştırmaların 
temel şartlarındandır. Çalışmada Oxford Mutluluk Ölçeğinin faktör analizine uygunluğunun belirlenmesi için küresellik sınaması ve verilerin birbirleriyle ilişkili olup olmadığını belirleyen Bartlett Sınaması ve araştırmadaki örneklem büyüklügünün faktör analizi için uygunluğunu sinamakta Kaiser - Mayer - Olkin (KMO) ölçütüne bakılmış; Bartlett Sınaması Değeri $=1685,33$ ve KMO $=0.861$ olarak hesaplanmıştır. (Güriş ve Astar, 2014: 245, 246; Büyüköztürk, 2017; Bilge ve Bal, 2012: 140; Yılmaz vd., 2009: 131-132) . Sosyal bilimler alanında yapılan çalışmalarda KMO değerinin 0,60 ve büyük olması ana kütleden çekilen örneklem büyüklüğünün araştırma için yeterli olduğunun göstergesidir. Hesaplanan istatistiki değerler doğrultusunda, verilerin faktör analizi için uygun olduğu görülmüştür. Açıklayıcı faktör analizi sonucunda 5 faktör elde edilmiş, 6 . faktör ise oluşmamıştır.

\section{Doğrulayıcı Faktör Analizi Sonuçları:}

AFA aracılığıyla bulunan beş boyutluluğun doğrulanması Manisa Büyükşehir Belediyesi verileri kullanılmak suretiyle DFA ile LISREL 8.80 paket programı kullanılarak elde edilmiştir. Elde edilen sonuçlar Şekil 1'de verilmiştir. Modelin uygunluğu çoklu uyum kriterleri dikkate alınarak değerlendirilmiştir. Ölçütler KiKare $=362,57($ s.d. $=198),\left(\chi^{2} /\right.$ s.d. $)=1,83 ; \operatorname{RMSE}=0,064 ; \mathrm{NFI}=0,89 ; \mathrm{NNFI}=$ 0,$94 ; \mathrm{CFI}=0,94 ; \mathrm{GFI}=0,86 ; \mathrm{RMR}=0,07 ; \mathrm{SRMR}=0,06$

kabul edilebilir uyum ölçütleri arasında yer almıştır. Bu sonuçlar ölçekten elde edilen faktörlerin uygun olduğunu göstermektedir. Hem AFA hem de DFA sonuçları (OMÖ) yapısının bize beş boyutlu olduğunu, iç tutarlık ve güvenirlik sonuçları da yeterli düzeydedir. 


\section{H. BİLGE}

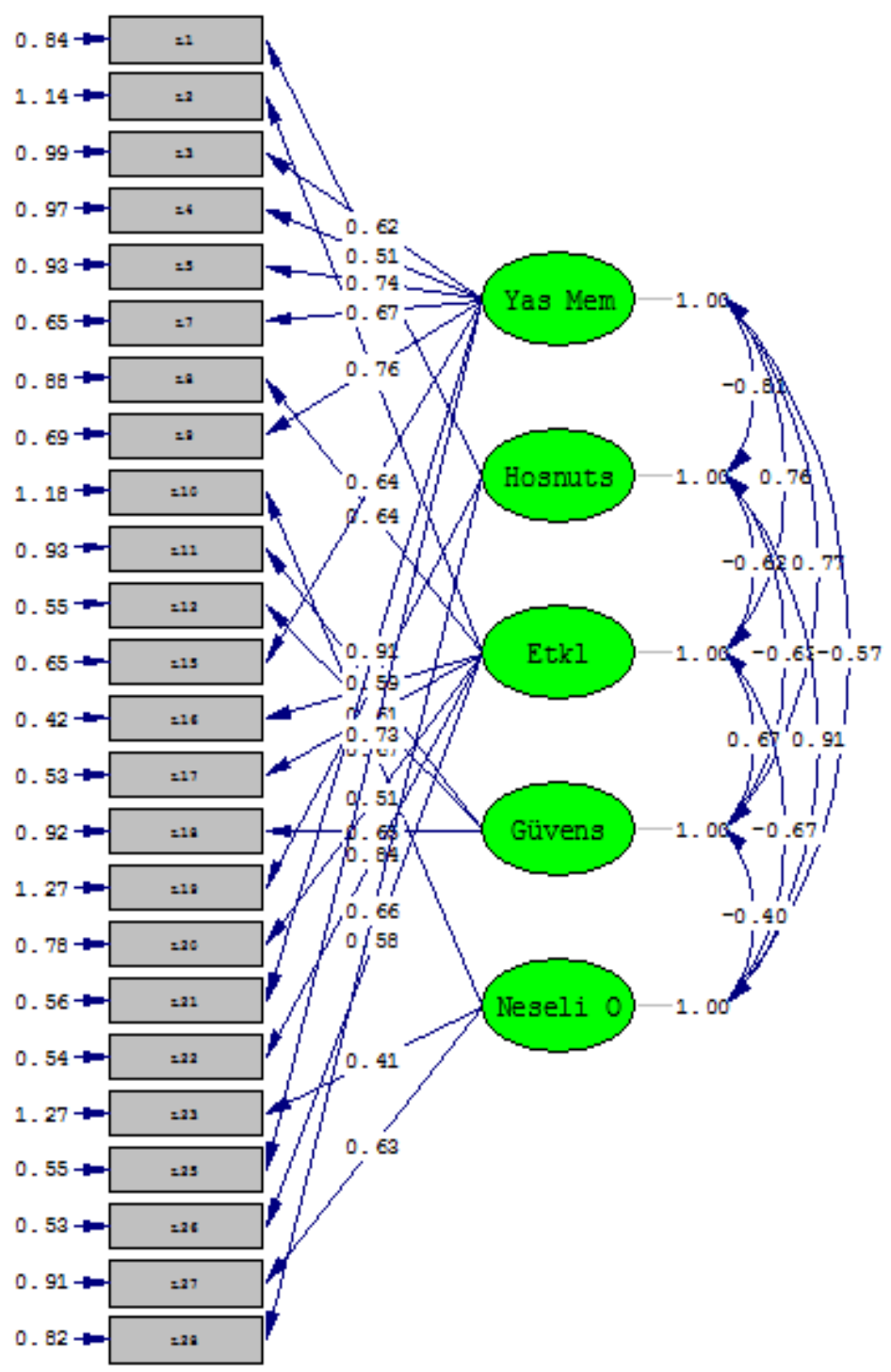

Chi-3quare $=447.55, \mathrm{df}=242, \mathrm{p}-\mathrm{value}=0.00000, \mathrm{RMSEA}=0.065$

Şekil 1. Mutluluk Alt Boyutları DFA Sonuçları

\subsection{Cinsiyetin, Mutluluk Üzerine Etkisi İçin t Test Analizi}

Tablo 2: Betimleyici İstatistikler

\begin{tabular}{l|lrrr}
\multicolumn{2}{c}{} & N & Ortala. & Stand. Sapma \\
\hline \multirow{2}{*}{ Yaşam Memnuniyeti } & Erkek & 83 & 3,38 &, 789 \\
& Kadın & 120 & 3,51 &, 730 \\
Hoşnutsuzluk & Erkek & 83 & 2,33 &, 802 \\
& Kadın & 120 & 2,09 &, 756
\end{tabular}




\begin{tabular}{l|lrrr} 
Etkililik & Erkek & 83 & 3,71 &, 709 \\
Neşeli Olma & Kadın & 120 & 3,81 &, 653 \\
& Erkek & 83 & 3,33 &, 838 \\
Güvensizlik & Kadın & 120 & 3,55 &, 767 \\
& Erkek & 83 & 2,47 &, 882 \\
Kadın & 120 & 2,54 &, 796
\end{tabular}

Araştırmaya katılan erkek belediye çalışanların sayısı kadınlara göre daha az sayıdadır. Ortalamalarına baktığımızda kadınların yaşam memnuniyeti, etkililik, neşeli olma ve güvensizlik boyut ortalamalı erkeklere göre daha yüksektir. Erkeklerde ise sadece hoşnutsuzluk boyut ortalaması kadınlara göre daha yüksektir

Tablo 3: Cinsiyetin Mutluluk Üzerine Etkisi İçin t Test Analizi Sonuçları

Serb. Derecesi Önem.

\begin{tabular}{l|rrr}
\hline Yaşam Memnuniyeti & $-, 1,161$ & 159 &, 247 \\
Hoşnutsuzluk & 2,151 & 159 &, 033 \\
Etkililik & $-1,000$ & 159 &, 318 \\
Neşeli Olma & $-1,982$ & 159,049 \\
Güvensizlik &,- 601 & 159,549
\end{tabular}

Tablo 3'teki analiz sonuçları incelendiğinde, araştırmaya katılan belediye çalışanların cinsiyetlerinin mutluluk alt boyutlarından "hoşnutsuzluk" $(\mathrm{p}=0,033<0,05)$ ve "neşeli olma" $(\mathrm{p}=0,049<0,05)$ üzerinde 0,05 anlamlılık düzeyine göre önemli bir etkisi olduğu görülmüsştür.

\subsection{Katılımcıların Yaşlarının Mutluluk Alt Boyutları Üzerine Etkisine}

\section{Yönelik Bulgular}

Tablo 4: Katılımcıların Yaşlarının Mutluluk Alt Boyutları Üzerine Etkisinin Varyans Analizi Test Sonuçları

F Önem.

\begin{tabular}{l|rr}
\hline Yaşam Memnuniyeti & 1,528 &, 195 \\
Hoşnutsuzluk &, 796 &, 529 \\
Etkililik & 1,078 &, 368 \\
Neşeli Olma & 1,589 &, 179 \\
Güvensizlik &, 551 &, 699
\end{tabular}




\section{H. BİLGE}

Tablo 4'deki analiz sonuçları incelendiğinde yaş değişkeninin, mutluluk alt boyutları üzerine istatistiksel olarak anlamlı bir etkisi yoktur.

4.5. Katılımciların Medeni Durumlarının Mutluluk Alt Boyutları Üzerine Etkisine Yönelik Bulgular

Tablo 5: Katılımcıların Medeni Durumlarının Mutluluk Alt Boyutları Üzerine Etkisinin Varyans Analizi Test Sonuçları

\begin{tabular}{|c|c|c|}
\hline & $\mathrm{F}$ & Önem. \\
\hline Yaşam Memnuniyeti & 1,723 &, 163 \\
\hline Hoşnutsuzluk & 1,061 &, 367 \\
\hline Etkililik & 3,050 &, 030 \\
\hline Neşeli Olma & 2,628 &, 051 \\
\hline Güvensizlik & ,995 &, 396 \\
\hline
\end{tabular}

Sonuçlar incelendiğinde, medeni durum değişkenin "etkililik" $(p=0,030<0,05)$ alt boyutu üzerinde 0,05 anlamlılık düzeyine göre istatistiksel olarak anlamlı fark oluşturmaktadır. Gruplar arasında fark olduğu için Tukey testine geçmeden önce varyansların homojenlik testi yapılmıştır; etkililik faktörünün $\mathrm{p}=0,456>0,05$ olduğundan varyans homojen dağılmıştır. Tablo 5'daki analiz sonuçlarına göre anlamlı bulunan faktörlere ilişkin ikili karşılaştırmalar (TUKEY Testi) yapılmıştır.

Tablo 6: Medeni Durumun Mutluluk Alt Boyutları Üzerine Etkisinin İkili Karşılaştırılması (Post Hoc Tests-Tukey) Testi Sonuçları

\begin{tabular}{lccrc} 
Bağımlı Değişk. & $(\mathrm{I})$ Kıdem & $(\mathrm{J})$ Kıdem & Ort. Fark. (I-J) & Önem. \\
\hline \multirow{2}{*}{ Etkililik } & Dul & Boşanmı̧s & $-1,01276$ &, 022 \\
\hline
\end{tabular}

Tukey Testinde, medeni durum değişkeninin mutluluk boyutlarından "etkililik" $(\mathrm{p}=0,022<0,05)$ boyutu üzerinde fark oluşsturduğu görülmektedir. Belediye çalışanların dul olanları boşanmış olan çalışanlara göre yaşamında ve iş ortamında daha fazla etkili olduğu belirlenmiştir. 


\subsection{Katılımcıların Eğitimlerinin Mutluluk Alt Boyutları Üzerine} Etkisine Yönelik Bulgular

Tablo 7: Katılımcıların Eğitimlerinin Mutluluk Alt Boyutları Üzerine Etkisinin Varyans Analizi Test Sonuçları

\begin{tabular}{l|rr}
\multicolumn{1}{c}{} & \multicolumn{1}{c}{ F } & Önem. \\
\hline Yaşam Memnun. &, 400 &, 809 \\
Hoşnutsuzluk &, 950 &, 436 \\
Etkililik & 3,180 &, 015 \\
Neşeli Olma &, 813 &, 518 \\
Güvensizlik &, 798 &, 528
\end{tabular}

Sonuçlar incelendiğinde, eğitim değişkenin "etkililik" $(\mathrm{p}=0,015<0,05)$ alt boyutu üzerinde 0,05 anlamlılık düzeyine göre istatistiksel olarak anlamlı fark oluşturmakta ve homojenlik testi sonucu ise etkililik faktörünün $p=0,961>0,05$ olduğundan varyans homojen dağılmıştır. Tablo 7'daki analiz sonuçlarına göre anlamlı bulunan faktörlere ilişkin ikili karşılaştırmalar (TUKEY Testi) yapılmıştır.

Tablo 8: Eğitimin Mutluluk Alt Boyutları Üzerine Etkisinin İkili Karşılaştırılması (Post Hoc Tests-Tukey) Testi Sonuçları

\begin{tabular}{lllrrr} 
Bağımlı Değ. & (I)Kıdem & (J)Kıdem & Ort. Farklar(I-J) & Standart Hata & \multicolumn{2}{c}{ Önem. } \\
\hline Etkililik & Lisans & Orta Öğretim &, 35275 &, 11296 &, 017 \\
\hline
\end{tabular}

Tablo 8'deki analiz sonucuna göre, yapılan Tukey testinde, eğitimin mutluluk alt boyutlarından "Etkililik” boyutu üzerinde fark oluşturduğu görülmektedir. Manisa Büyükşsehir merkez teşkilatında lisans mezunu çalışanların orta öğretim çalışanlarına göre kararlarında daha etkili oldukları ve böylece yaşamlarında daha mutlu oldukları söylenebilir.

\subsection{Katılımcıların Unvanlarının Mutluluk Alt Boyutları Üzerine} Etkisine Yönelik Bulgular 


\section{H. BİLGE}

Tablo 9: Katılımcıların Unvanlarının Mutluluk Alt Boyutları Üzerine Etkisinin Varyans Analizi Test Sonuçları

F Önem.

\begin{tabular}{l|rr}
\hline Yaşam Memnuniyeti & 1,751 &, 158 \\
Hoşnutsuzluk &, 422 &, 737 \\
Etkililik & 3,031 &, 030 \\
Neşeli Olma & 1,278 &, 283 \\
Güvensizlik &, 497 &, 685
\end{tabular}

Sonuçlar incelendiğinde, eğitim değişkenin “etkililik" $(\mathrm{p}=0,030<0,05)$ alt boyutu üzerinde 0,05 anlamlılık düzeyine göre istatistiksel olarak anlamlı fark oluşturmakta ve homojenlik testi sonucu ise etkililik faktörünün $p=0,213>0,05$ olduğundan varyans homojen dağılmıştır. Tablo 9'daki analiz sonuçlarına göre anlamlı bulunan faktörlere ilişkin ikili karşılaştırmalar (TUKEY Testi) yapılmıştır.

Tukey testinde, unvanın mutluluk alt boyutlarından "Etkililik" boyutu üzerinde fark oluşturmadığı görülmüştür. Manisa Büyükşehir merkez teşkilatında çalışanların unvan bazında daha etkili oldukları istatistiksel olarak belirlenmiş fakat hangi unvanların daha etkili olduğu Tukey Testinde belirlenememiştir.

\subsection{Katılımcıların Çalışma Sürelerinin Mutluluk Alt Boyutları} Üzerine Etkisine Yönelik Bulgular

Tablo 10: Katılımcıların Çalışma Sürelerinin Mutluluk Alt Boyutları Üzerine Etkisinin Varyans Analizi Test Sonuçları

\begin{tabular}{l|rr}
\multicolumn{1}{c}{ F } & Önem. \\
\hline Yaşam Memnuniyeti &, 746 &, 526 \\
Hoşnutsuzluk & 1,981 &, 118 \\
Etkililik & 1,679 &, 173 \\
Neşeli Olma & 2,523 &, 059 \\
Güvensizlik &, 058 &, 982
\end{tabular}

Tablo 10'daki analiz sonuçları incelendiğinde araştırmaya katılan Manisa Büyükşehir merkez teşkilatında çalışanların belediyede çalışma sürelerinin 
mutluluğun alt boyutları üzerine 0,05 anlamlılık düzeyine göre istatistiksel olarak anlamlı bir etkisi olmadığı görülmüştür.

\subsection{Katılımcıların Sosyal Yaşama Katılımlarının Mutluluk Alt} Boyutları Üzerine Etkisine Yönelik Bulgular

Tablo 11: Katılımcıların Sosyal Yaşama Katılımlarının Mutluluk Alt Boyutları Üzerine Etkisinin Varyans Analizi Test Sonuçları

\begin{tabular}{l|rr}
\multicolumn{1}{c}{ F } & Önem. \\
\hline Yaşam Memnuniyeti & 5,660 &, 004 \\
Hoşnutsuzluk & 3,199 &, 043 \\
Etkililik & 2,325 &, 100 \\
Neşeli Olma & 10,688 &, 000 \\
Güvensizlik & 1,318 &, 270
\end{tabular}

Sonuçlar incelendiğinde, sosyal yaşama katılım değişkenin "yaşam memnuniyeti, hoşnutsuzluk ve neşeli olma" $(\mathrm{p}=0,015<0,05)$ alt boyutları üzerinde 0,05 anlamlılık düzeyine göre istatistiksel olarak anlamlı fark oluşturmakta ve homojenlik testi sonucu ise "yaşam memnuniyeti, hoşnutsuzluk ve neşeli olma" faktörlerinin sirasiyla $\mathrm{p}=0,994>0,05 ; \mathrm{p}=0,919>0,05$ ve $\mathrm{p}=0,245>0,05$ olduğundan varyans homojen dağılmıştır. Tablo11'deki analiz sonuçlarına göre anlamlı bulunan faktörlere ilişkin ikili karşılaşıtırmalar (TUKEY Testi) yapılmıştır.

Tablo 12: Sosyal Yaşama Katılımlarının Mutluluk Alt Boyutları Üzerine Etkisinin İkili Karşılaştırılması (Post Hoc Tests-Tukey) Testi Sonuçları

Bağımlı Değiş. $\quad$ (I) Kıdem (J) Kıdem Orta. Farklar (I-J) Önem.

\begin{tabular}{l|clll}
\hline Yaşam memn. & Çok & Düşük &, 20609 &, 014 \\
& Orta & Düşük &, 33320 &, 014 \\
\hline \multirow{2}{*}{ Hoşnutsuzluk } & Düşük & Çok &, 49444 &, 036 \\
\hline \multirow{2}{*}{ Neşeli Olma } & Çok & Orta &, 55412 &, 008 \\
& Çok & Düşük &, 89365 &, 000 \\
& Orta & Düşük &, 33953 &, 049
\end{tabular}

Analiz sonucuna göre, yapılan Tukey testinde, sosyal yaşama katılım değişkeninin, mutluluk alt boyutlarından "yaşam memnuniyeti”, "hoşnutsuzluk” ve "neşeli olma" boyutları üzerinde fark oluşturduğu görülmektedir. Manisa 


\section{H. BİLGE}

Büyükşehir merkez teşkilatında çalışanların sosyal yaşama daha fazla ve orta düzeyde katılanların az katılanlara göre kişisel mutluluklarının oldukça fazla oldukları söylenebilir.

\section{SONUC VE ÖNERILLER}

Türkiye'de büyükşehir belediyecilik sistemi, 2012 yılı aralık ayında çıkartılan 6360 sayılı Kanun ile yerel yönetim mevzuatında çok önemli boyutta değişiklikler yapmıştır. Çıkartılan bu kanunun getirdiği değişikliklerden biri de belediye mücavir alanını il sınırına eşitlemesidir. Ayrıca ikili bir yapı oluşturacak şekilde, sadece büyükşsehirlerde il özel idarelerinin, belde belediyelerinin ve köylerin tüzel kişilikleri ortadan kaldırılmış, tüm köyler mahalle statüsüne dönüştürülmüştür. Yerel yönetim mevzuatındaki değişiklik, coğrafî sınırları çok geniş ve nüfusu çok yoğun olan bu illerde yerel hizmetlerin etkin, verimli ve ekonomik olarak yerine getirilmesi (Tekin, 2018: 85), bir anlamda büyükşehir belediyelerinde çok daha etkin bir yönetim biçimine geçilmesini zorunlu kılmıştır. Belediyeler, yerinden yönetim modeliyle yöre halkının belirli oranda katılımları teşvik edilerek modern bir yönetim anlayışı sergileyerek, hizmet sunulan bölgenin yaşam standartlarını yükseltilmesi mümkün olabilecektir. Aslında, belediyeleri insan kaynakları odaklı hizmet işletmeleri şeklinde düşünülmesi ve yönetilmesi de bu bağlamda önemlidir.

Çalışmada, Manisa Büyükşehir il merkezinde çalışan personelin etkin ve verimli hizmet sunumunu yapabilmeleri, bir anlamda, kendilerinin yönetim biçimlerine bağlı olacaktır. Belediyelerde belirlenen yönetim biçimleri, onları cesaretlendirici, onurlandırıcı, yetki göçeriminin yapılması, sürekli gelişim odaklı eğitim ihtiyaçlarının belirlenip eğitimin verilmesi, performans ve kariyer odaklı yaklaşım vb. durumların belediye çalışanının kişisel mutluluklarını arttırıcı ve sonuçsal bağlamda işyeri mutluluk olgusunu da odak hale getirebilecektir.

$\mathrm{Bu}$ çalışma, ilgili literatüre önemli katkılar sağlamıştır. Birincisi, çalışmada kullanılan Oxford Mutluluk Ölçeği alt boyutlarının tespiti ve isimlendirilmesi literatürde ( Doğan ve Sapmaz, 2012; Hills ve Argyle,1998-2002) elde edilememiş ve bu çalışmada alt boyutlarının AFA ile belirlenmesi, DFA ile güvenirliklerin sağlanması ve alt boyutların isimlendirilmesi yapılmıştır. 
Çalışmanın literatüre ikinci katkısı ise Oxford Mutluluk Ölçeğinin bu çalışmada beş boyut ile ölçülmesi olmuştur. Literatürde, şimdiye kadar yapılmış olan çalışmalarda ( Doğan ve Sapmaz, 2012; Hills ve Argyle,1998-2002) Oxford Mutluluk Ölçeği genellikle bir boyut ile alınmış ve kavramlaştırılmıştır. Çalışmada ise Oxford Mutluluk Ölçeği beş boyutta işlemsel hale getirilerek, konu daha kapsamlı ölçülmüş ve çalışanların mutlulukları kurumsal bazda yaşam memnuniyetleri, hoşnutsuzlukları, etkililikleri, neşeli olmaları ve güvensizliklerinin ölçülmesi gerçekleştirilmiştir.

\section{Çalışmanin hipotezlerinin incelenmesi:}

"Cinsiyet", mutluluk alt faktörlerinden sadece "hoşnutsuzluk" ve "neşeli olma" boyutları üzerinde anlamlı bir etkiye sahiptir. Bu boyutların betimsel istatistiklerine baktığımızda erkeklerin daha çok hoşnutsuzluk duygusu yaşadıkları kadınların ise neşeli olma duygusuna sahip oldukları gözlemlenmiştir. Bu hipotezde, hoşnutsuzluk boyutunda en yüksek değere sahip soru "kendimi çok sağlıklı hissetmiyorum; kendimden hoşnut değilim" şeklinde erkekler cevap vermişlerdir. Bu boyutta kadınlar ise en yüksek oranda cevap verdikleri soru" çok gülen birisiyim; yapmak istediğim her şeye zaman bulabilirim" şeklindedir. Bir anlamda kadınların çok neşeli ve zamanları bol, erkeklerin ise kendilerini sıkıntıda ve sağlıklı hissetmedikleri belirlenmiştir.

Çalışanların, "yaş" ve "çalışma süreleri" bağımsız değişkenleri bağımlı değişkenler olan mutluluğun alt boyutları üzerinde herhangi bir etkiye sahip olmadığı gözlenmiştir.

"Medeni durum" ve "eğitim" değişkenlerinin, mutluluğun alt boyutlarından sadece "etkililik" boyutu üzerinde anlamlı bir etkiye sahiptirler. Burada eşinden boşanmış olanların eşi vefat etmiş olanlara göre işlerinde ve kişisel yaşamlarında daha etkili oldukları belirlenmiştir. En yüksek skora sahip soru "genellikle olaylar üzerinde olumlu etkim vardır” şeklindedir. Boşanmış çalışanların dul çalışanlara oranla ve ayrıca lisans mezunu olanların da orta öğretim mezunlarına göre, daha ilgili ve etkili olması onların özgüven artışlarıyla birlikte mutluluklarında artış olduğu yönündedir.

"Unvan" bağımsız değişkeni mutluluk alt boyutlarından yine "etkililik" boyutu üzerinde anlamlı etkiye sahip olmasına karşın, Tukey testinde hangi unvanların daha etkili oldukları belirlenememiştir. 


\section{H. BİLGE}

"Sosyal yaşama katılma" değişkeninin mutluk alt faktörlerinden "yaşam memnuniyeti", "hoşnutsuzluk" ve "neşeli olma" boyutları üzerinde anlamlı olarak etkilemiştir. Belediye çalışanlarının sosyal yaşama dahil olmaları onları oldukça mutlu etmektedir.

Sonuç olarak, bu çalışma sadece yeni kurulan Manisa Büyükşehir Belediyesi il merkezinde çalışan tüm personel dikkate alınarak yapılması istatistik birimlerinin şekilsel homojenliği sağladığı kabul edilebilir. Elde edilen sonuçların uygunluğu diğer büyükşehir belediyeleri çalışanlarına da uygulanarak sonuçların güvenirliği ve tekrar edilebilirliği araştırılmalıdır. Oxford Mutluluk Ölçeğinin alt boyutlarının tespiti ve isimlendirilmesi önemlidir. $\mathrm{Bu}$ boyutların güvenirliği için farklı kurumlarda da çalışmalar yapılarak desteklenmesi, bu ölçeğin tek boyutlu kullanım yerine çoklu boyutlu olarak kullanılması, çalışanların mutluluğunu belirlemede fayda sağlayabilir. Diğer çalışmalarda özellikle kadın çalışanların mutsuzluk nedenleri ve tüm çalışanların hangi tür sosyal yaşamı istedikleri belirlenmeli ve pozitif olanlar desteklenmesi kurumlar için önemli olacaktır.

\section{KAYNAKÇA}

ARGYLE, M. (2013), The Psychology of Happiness, (2. Bask1), Routledge.

ARGYLE, M., MARTIN, M., CROSSLAND, J., (1989), "Happiness as a Function of Personality and Social Encounters", Recent Advances in Social Psychology: An International Perspective, 189-203.

BİLGE, H., BAL, V., (2012), "Girişimcilik Eğilimi: Celal Bayar Üniversitesi Öğrencileri Üzerine Bir Araştırma", Süleyman Demirel Üniversitesi Sosyal Bilimler Enstitüsü Dergisi, 2, Say1:16, 131-148.

BÜYÜKÖZTÜRK, Ş. (2017), Sosyal Bilimler İçin Veri Analizi El Kitabı, Pegem Akademi (23. Bask1), Ankara.

BYRNE, B.M. (1998), Structural Equation Modeling with LiSREL, PRELIS AND SIMPLIS: Basic Consepts, Applications and Programming, Lawrence Erlbaum Associates, İnc., New Jersey.

CSIKKSZENTMIHALYİ, M. (1992), The Psychology of Happiness, Kent: Mackays of Chatham plc.

ÇELIK, H. E., YILMAZ, V. (2013), LISREL 9.1 ile yapısal eşitlik modellemesi, temel kavramlar-uygulamalar-programlama, (2.Bask1), Anı Yayınc1lı, Ankara.

DİENER, E., SAPYTA, J. J., VE SUH, E. M. (1998), “Subjective Well-Being İs Essential To Well-Being", Psychological Inquiry, 9(1), 33-37.

DOĞAN, T., ÇÖTOK, N. A. (2011), "Oxford mutluluk ölçeği kısa formunun Türkçe uyarlaması: Geçerlik ve güvenirlik çalışması”, Türk Psikolojik Danışma ve Rehberlik Dergisi, 4(36), 165-170. 
DOĞAN, T., SAPMAZ, F. (2012), “Oxford Mutluluk Ölçeği Türkçe Formunun Psikometrik Özelliklerinin Üniversite Öğrencilerinde İncelenmesi”, Düşünen Adam Psikiyatri ve Nörolojik Bilimler Dergisi, 25(4), 297-304.

EGE, N., (2018), Örgütsel Sessizlik ve Mutluluk İlişkisinin İncelenmesi: Gediz Elektrik Dağıtım A.Ş. Örneği, Dokuz Eylül Üniversitesi Sosyal Bilimler Enstitüsü Yüksek Lisans Tezi.

GAVIN, J. H., MASON, R. O., (2004), “The Virtuous Organization:: The Value of Happiness in the Workplace", Organizational Dynamics", 33(4), 379-392.

GRANDEY, A.A., DİEFENDORFF, M. VE RUPP, D.,E., (2013), Emotional Labor in the 21. Centruy, Taylor\&Francis.

GÜRIŞ, S., ASTAR, M., (2014), Bilimsel Araştırmalarda SPSS ile İstatistik, Der Yayınları, İstanbul.

HILLS, P., VE ARGYLE, M. (1998), "Positive moods derived from leisure and their relationship to happiness and personality", Personality and individual differences, 25(3), 523-535.

HILLS, P., ARGYLE, M. (2002), "The Oxford Happiness Questionnaire: a compact scale for the measurement of psychological well-being", Personality and individual differences, 33(7), 1073-108.

HOX, J.J., BECHGER, T.M. (2003), "An Introduction to Structual Equation Modelling", Family Sciences Review, No:11, 354-373.

JÖRESKOG, K., SÖRBOM, D. (1996-2001), LiSREL 8: User's Reference Guide, Scientıfic Software International.

KAMTHAN, S., SHARMA, S., BANSAL, R., PANT, B., SAXENA, P., CHANSORİA, S., SHUKLA, A. (2018), "Happiness Among Second Year MBBS Students and its Correlates Using Oxford Happiness Questionnaire", Journal of Oral Biology and Craniofacial Research.

KIM-PRIETO, C., DİENER, E., TAMIR, M., SCOLLON, C. N., DIEENER, M. (2005), "Integrating the Diverse Definitions of Happiness: A Time-Sequential Framework of Subjective Well-Being", Journal of Happiness Studies, 6(3), 261300.

KLINE, R.B. (2011), Principles and Practice of Structural Equation Modeling, The Guilford Pres (Third Edition), New York.

MEDVEDEV, O. N., Sİegert, R. J., Mohamed, A. D., Shepherd, D., Landhuis, E., Krägeloh, C. U. (2017), “The Oxford Happiness Questionnaire: Transformation From an Ordinal to An İnterval Measure Using Rasch Analysis", Journal of Happiness Studies, 18(5), 1425-1443.

SCHERMELLEH-ENGEL, K., MOOSBRUGGER, H., MÜLER, H. (2003), "Evaluating The Fit of Structural Equation Models: Tests of Significance and Descriptive Goodness-of-fit Measures", Methods of Psychological Research Online, 8(2), 23-74, www.mpr-online.de, (24.12.2012). 


\section{H. BİLGE}

SEVGILİ GENÇAY, F.D., (2018), "Belediye Şirketlerinin Hukuki Statüsü", TBB Dergisi (134), 153-176.

ŞIMŞEK, Ö. F., (2007), Yapısal eşitlik modellemesine giriş:(temel ilkeler ve LISREL uygulamalarl). Ekinoks.

TEKIN, Ö. F. (2018), “Türkiye'de Büyükșehir Yönetimi ve 6360 Sayılı Yasanın Getirdiği Değişim: Konya Örneği”, Dumlupınar Üniversitesi Sosyal Bilimler Dergisi, (55), 84-105.

VEENHOVEN, R. (1991), "Is happiness relative?", Social indicators research, 24(1), 1-34.

YILMAZ, V., ŞEN, H., (2013), "Examination of the Effect of Job Satisfaction on Burnout of University Teaching Staff with Structural Equation Model", Arts, Socıal Sclences, 73-83.

YILMAZ, V., AKTAŞ, C., ARSLAN, M.S.T., (2009), "Müşterilerin Kredi Kartına Olan Tutumlarının Çoklu Regresyon ve Faktör Analizi İle İncelenmesi", Balıkesir Üniversitesi Sosyal Bilimler Enstitüsü Dergisi, 12/22, 127-139.

YILMAZ, V, ÇATALBAŞ, G.K., ÇELIK, H.E. (2009), "Kredi Kartı Kullanma Niyetini Etkileyen Faktörlerin Yapısal Eşitlik Modeliyle Araştırılması", Bankacılar Dergisi,Say1 68, 20-29.

YILMAZ, V., ÇELIK, H.E., ARSLAN, M.S.T. (2010), "Enerji Çeşitleri ve Geri Dönüşüme Karş1 Tutumların Çevresel Davranışa Etkisi”, Firat Üniversitesi Sosyal Bilimler Dergisi, Cilt: 20, Say1: 2, 323-342.

YÜKSEKBILliILİ, Z., AKDUMAN, G. (2015), "Sağl1k Personelinin Mutlulukları Üzerine Bir Alan Araştırması: Aile Sağlığı Merkezlerinde Bir Uygulama", Finans Ekonomi ve Sosyal Araştırmalar Dergisi (FESA), 1(1), 71-84. 